\title{
Tobacco Industry Wastewater-Induced Genotoxicity in Mice Using the Bone Marrow Micronucleus and Sperm Morphology Assays
}

\author{
Okunola A. Alabi ${ }^{1 *}$, Evi Osifo-Whiskey ${ }^{1}$, Precious Yadi ${ }^{1}$, \\ Moruf Lawal ${ }^{1}$, and Adekunle A. Bakare ${ }^{2}$ \\ ${ }^{1}$ Department of Biosciences and Biotechnology, Babcock University, \\ Ilisan Remo, Ogun State, Nigeria \\ ${ }^{2}$ Cell Biology and Genetics Unit, Department of Zoology, University of Ibadan, \\ Ibadan, Nigeria
}

Received November 11, 2013; accepted April 8, 2014

\begin{abstract}
Summary The tobacco industry is one of the biggest industries in the world. Large quantities of wastewater are generated during processing and cigarette-making which may be toxic to the environment and public health. In this study, the potential genotoxicity of tobacco wastewater was evaluated using mice bone marrow micronucleus and sperm morphology assays. The wastewater was considered at concentrations of $1,5,10,25,50,75$ and $100 \%$ (v/v, wastewater/distilled water). There was concentration-dependent induction of micronucleated erythrocytes at all tested concentrations, with significant $(p<0.05)$ induction at $25,50,75$ and $100 \%$ concentrations compared to the negative control. Assessment of sperm shape showed a significant increase in sperm abnormalities with significant decrease in mean sperm count in treated groups. $\mathrm{Cd}, \mathrm{Cu}, \mathrm{Zn}, \mathrm{Ni}$ and Co analysed in the wastewater contributed significantly to these observations. This shows that tobacco wastewater constituents are capable of inducing somatic and germ cell mutations.
\end{abstract}

Key words Genotoxicity, Tobacco, Micronucleus, Sperm morphology, Wastewater.

The tobacco industry is one of the biggest industries in the world. The economical value of the tobacco and cigarette production industry was more than three quadrillion dollars (Gönen 2005). Large amounts of cigarettes are being produced in the world. The top producers of tobacco in descending order of production are China, USA, Russia, Japan, Indonesia, Germany, Turkey, Korea, Netherlands, UK, Brazil and India (Production of Tobacco 2005). Developing countries consume $70 \%$ of cigarettes produced in the world (World Tobacco Consumption 2005). The processes used in this industry are confidential because of economical and rivalry reasons. The companies have to keep their product contents and their production technologies secret for several reasons. Today's manufacturing of tobacco products is quite different from the ancient methods; it includes many chemical additions to provide a better taste (Gönen 2005). Since every brand has its own secret flavor, it is almost impossible to know the exact composition of these products. Nontobacco smoking materials and denicotinization are other unknowns about tobacco manufacturing.

Tobacco manufacturing can be considered as a two-step process. The first step is the production of tobacco, which mainly consists of physical operations such as drying and cutting that do not contribute to wastewater production. In the later stages, nicotine, synthetic flavoring agents and residues of pesticides reach the wastewater (Chidambara and Han 2004). The tobacco manufacturing process produces liquid, solid, and airborne wastes. Liquid wastes include tobacco

*Corresponding author, e-mail: alabiokuola@yahoo.com

DOI: $10.1508 /$ cytologia.79.215 
slurries, solvents, oils, and greases that originate from the manufacturing processes, building services, and facilities that may need special treatment or disposal. Solid wastes include paper, wood, plastics, unusable tobacco, packaging materials and dirt that originate in the manufacturing process. These waste products are resold, recirculated, compacted, or put in landfills (Gönen 2005). Airborne wastes include non-toxic odors of manufacturing, in-plant dust, tobacco volatiles and particles, and other emissions. Abatement programmes for airborne wastes include use of filters, dust collectors and scrubbers, low-sulphur fuels and other controls (Novotny and Zhao 1999). Tobacco industry wastewater contains some toxic contaminants which inhibit the microbial consortium in biological treatment plants. Sources of these toxic contaminants are nicotine, flavoring chemicals containing glycogen and alcohol, adsorbable organic halogens (AOX), and pesticides from tobacco leaves (Sponza 2002). Nicotine, one of the major constituents of tobacco wastewater, is designated by the EPA as a Toxics Release Inventory (TRI) chemical. In 1992, the United States Toxics Release Inventory reported that tobacco manufacturing generated more than 27 million kilograms of production-related chemical waste, of which 2.2 million kilograms were treated or released into the environment. Overall, the tobacco industry ranked 18th among all industries in total chemical waste production (Novotny et al. 2009).

In spite of the large quantities of wastewater generated by the tobacco industry and the potential environmental and public health effect, there is little information in the literature on the toxicity of the tobacco industry wastewater and no information on the genotoxicity of this type of waste using animal bioassays. This study is therefore aimed at assessing the genotoxicity of tobacco industry wastewater using the mouse micronucleus and sperm morphology assays.

\section{Materials and methods}

\section{Sampling site and sample collection}

The sampling site is the British American Tobacco (BAT) Company, located at Ibadan toll gate, Oyo State, Nigeria. The company has been in existence since 2001. Wastewater from BAT (designated BWW) was collected at the end of the production line into a sterile $25-\mathrm{L}$ plastic container and immediately transported to the laboratory, where the sample was kept at $4^{\circ} \mathrm{C}$ throughout the period of the study. Tap water was used as control for the physico-chemical analysis.

\section{Determination of physical and chemical parameters}

The sample was analysed for a number of standard physical and chemical parameters including chemical oxygen demand (COD), total dissolved solids (TDS), alkalinity, biochemical oxygen demand (BOD), chlorides, nitrates, ammonia and phosphates according to methods described by APHA (1998). Eight heavy metals namely lead $(\mathrm{Pb})$, cadmium $(\mathrm{Cd})$, copper $(\mathrm{Cu})$, chromium $(\mathrm{Cr})$, iron $(\mathrm{Fe})$, zinc $(\mathrm{Zn})$, nickel $(\mathrm{Ni})$ and manganese $(\mathrm{Mn})$ were analysed in the wastewater according to standard analytical methods (USEPA 1996, APHA 1998). Briefly, $100 \mathrm{~mL}$ of the wastewater was digested by heating with concentrated $\mathrm{HNO}_{3}$ and the volume was reduced to $3-5 \mathrm{~mL}$. This volume was made up to $10 \mathrm{~mL}$ with $0.1 \mathrm{~N} \mathrm{HNO}_{3}$. The concentrations of the metals were estimated using an atomic absorption spectrophotometer (PerkinElmer AAnalyst 200, USA).

\section{Biological Materials}

Young male Swiss albino mice (Mus musculus, 6- and 10-11-weeks old) were obtained from the animal breeding unit of the Department of Physiology, University of Ibadan, Nigeria, and acclimatized for at least two weeks in a pathogen free, well-ventilated animal house of the Department of Biosciences and Biotechnology, Babcock University, Ilisan Remo, Ogun State, Nigeria. Food (Ladokun Pelleted Feed ${ }^{\circledR}$ ) and drinking water were supplied ad libitum. The mice 
were divided into two groups for each of the animal assay. Mice of eight weeks of age were used for the bone marrow micronucleus (MN) assay, while 12-14-week-old mice were used for the sperm morphology assay and sperm count. Animals were cared for according to standard guidelines (CIOMS 1985) and the policy laid down by the Animal Ethics Committee of our institute.

\section{Micronucleus test}

Seven groups of mice (four mice per group, 22-30 g each) were utilized in this assay to test concentrations of $1,5,10,25,50,75$ and $100 \%(\mathrm{v} / \mathrm{v}$, wastewater/distilled water) against negative (distilled water) and positive (cyclophosphamide, $20 \mathrm{mg} / \mathrm{kg}$ body weight) controls. Each mouse/ group was intraperitoneally (IP) exposed to $0.5 \mathrm{~mL}$ of each concentration for $96 \mathrm{~h}$. The IP route was favored since it is one of the fastest and most efficient means of delivering test chemicals into test animals in a short-term assay. Bone marrow preparation for micronuclei assessment was conducted according to the procedure of Schmid (1976) as modified by Alabi et al. (2013). Briefly, the animals were sacrificed by cervical dislocation. The femurs were removed from each and bone marrow flushed from the bones with fetal bovine serum (Sigma Aldrich Cheme GmbH, Germany). Cells were centrifuged at $2000 \mathrm{rpm}$ for $5 \mathrm{~min}$ and slides stained with May-Grunwald and Giemsa stains. At least 1000 cells/animal were scored for micronuclei in polychromatic erythrocytes (MNPCE). The differential staining of PCEs (bluish-purple) and normochromatic erythrocytes (NCEs, pinkish-orange), and the relative size of the erythrocytes are indices for differentiating them.

\section{Sperm morphology assay}

Induction of sperm abnormalities was studied according to Wyrobek et al. (1983) and Alabi and Bakare (2011). Seven concentrations of 1, 5, 10, 25, 50, 75 and 100\% (v/v, wastewater/distilled water) of the wastewater were considered together with the positive (cyclophosphamide, $20 \mathrm{mg} / \mathrm{kg}$ body weight) and negative (distilled water) controls. A single IP injection of $0.5 \mathrm{~mL}$ of the different test-sample concentrations was administered to the mice (five mice per group) daily for five consecutive days. Sperm was sampled from the caudal epididymes at five weeks from the first injection, since spermatogenesis in mice takes 34.5 days until completion (Bartke et al. 1974). The mice were sacrificed by cervical dislocation and their epididymes surgically removed. Two sperm suspensions were prepared from the cauda of each testis by mincing the cauda in physiological saline. Smears were prepared on grease-free slides after staining with $1 \%$ Eosin $Y$ for $45 \mathrm{~min}$. The slides were air-dried and coded for subsequent microscopic examination under oil immersion at 1000× magnification. For each mouse, 1000 sperm cells were assessed for morphological abnormalities according to the criteria of Wyrobek and Bruce (1975).

\section{Sperm counts}

The caput epididymes in the testes of animals used in sperm morphology assay were surgically removed and minced in physiological saline (Alabi et al. 2013). The counting of sperms was made from their suspension with the aid of the RBC counting chamber of Neubauers' heamatocytometer at $400 \times$ (Rastogi and Levin 1987). Pooled sperm count from five animals in each group was expressed as mean sperm count per $\mathrm{mL}$ of suspension.

\section{Statistical analysis}

The SPSS ${ }^{\circledR} 14.0$ statistical package was used for data analysis. Data obtained were expressed as percentage frequency and mean \pm standard deviation. Significance at the different dose-levels of each assay was tested by using the Dunett $t$-test and ANOVA. Differences between the negative control group and individual dose groups were analyzed at the 0.05 probability level. 


\section{Results}

\section{Physico-chemical analysis}

Table 1 presents the physico-chemical parameters analyzed in the tobacco wastewater and tap water, and the permissible limits in Nigeria (NESREA 2009) and the United States (USEPA 2009). The $\mathrm{pH}$ of the tobacco industry wastewater was acidic (4.2). BOD, alkalinity, nitrate, phosphate, ammonia, cadmium, copper, iron, zinc, nickel and cobalt levels were higher than in tap water and were above the allowable limit for drinkable water quality (NESREA 2009, USEPA 2009).

\section{Micronucleus test}

Compared with the negative control, there was a statistically significant $(p<0.05)$ concentration-dependent increase in $\mathrm{MN}$ at 25, 50, 75 and 100\% concentrations (Fig. 1). The maximum induction of $\mathrm{MN}$ was at the highest concentration of $100 \%$. The size and position of micronucleus in the cytoplasm showed slight variation and one MN/cell was observed (Fig. 2). There was also a concentration-dependent increase in normochromatic erythrocytes (NCE) at all concentrations tested with a significant $(p<0.05)$ increase at 50, 75 and $100 \%$ concentrations compared to the negative control (Fig. 1). The positive control induced a significant induction of $\mathrm{MN}$ compared to the negative control.

\section{Sperm morphology assay}

Figure $3 \mathrm{a}-\mathrm{i}$ shows the different sperm abnormalities observed in the mice exposed to the different concentrations of the tobacco industry wastewater. The frequencies of abnormal sperm cells in the negative and positive controls were $1.92 \%$ and $17.50 \%$, respectively. There were 1.96 , $2.54,4.02,5.50,10.04,11.64$ and $13.14 \%$ of abnormal sperm cells at the tested concentrations of 1 , $5,10,25,50,75$ and $100 \%$, respectively (Table 2). This induction of abnormalities was statistically

Table 1. Physico-chemical and heavy metal characteristics of tobacco industry wastewater.

\begin{tabular}{lllll}
\hline \hline Parameters* & Tap water & Tobacco wastewater & NESREA $^{\mathrm{a}}$ & USEPA $^{\mathrm{b}}$ \\
\hline $\mathrm{pH}$ & 7.1 & 4.20 & $6.5-8.5$ & $6.5-8.5$ \\
$\mathrm{COD}$ & 1.5 & 361.02 & 250 & 410 \\
$\mathrm{BOD}$ & 0.03 & 115.34 & 30 & 500 \\
TDS & 56.3 & 988.12 & 1200 & 20 \\
Alkalinity & 11.6 & 25 & 20 & 0.75 \\
Hardness & 0.23 & 13 & 75 & 250 \\
Chloride & 518.4 & - & 250 & 10 \\
Nitrate & $\mathrm{ND}$ & 42.62 & 10 & - \\
$\mathrm{Phosphate}$ & $\mathrm{ND}$ & 12.3 & 5 & 0.02 \\
$\mathrm{NH}$ & 24.6 & 21.41 & 0.5 & 0.1 \\
$\mathrm{Cr}$ & $\mathrm{ND}$ & $\mathrm{ND}$ & 0.1 & 0.005 \\
$\mathrm{Cd}$ & $\mathrm{ND}$ & 0.05 & 0.005 & 0 \\
$\mathrm{~Pb}$ & $\mathrm{ND}$ & 0.05 & 1 \\
$\mathrm{Cu}$ & $\mathrm{ND}$ & 0.24 & 0.05 & 0.3 \\
$\mathrm{Fe}$ & 4.85 & 2.16 & 0.03 & 5 \\
$\mathrm{Zn}$ & 0.625 & 3.05 & 1.5 & - \\
$\mathrm{Ni}$ & $\mathrm{ND}$ & 0.13 & 0.01 & 0.05 \\
$\mathrm{Mn}$ & 0.05 & $\mathrm{ND}$ & 0.1 & - \\
$\mathrm{Co}$ & $\mathrm{ND}$ & 0.10 & - & \\
\hline
\end{tabular}

Notes: $\mathrm{COD}=$ Chemical oxygen demand, $\mathrm{BOD}=$ biochemical oxygen demand, TDS=total dissolved solid, ND=Not detected.

${ }^{*}$ Units of the parameters are in $\mathrm{mg} \mathrm{L}^{-1}$ except for salinity in parts per thousand and $\mathrm{pH}$ which has no unit.

${ }^{a}$ National Environmental Standards and Regulation Enforcement Agency (2007) Permissible limits for drinking water.

${ }^{\mathrm{b}}$ USEPA - US Environmental Protection Agency. http://water.epa.gov/drink/contaminants/index.cfm\#List 


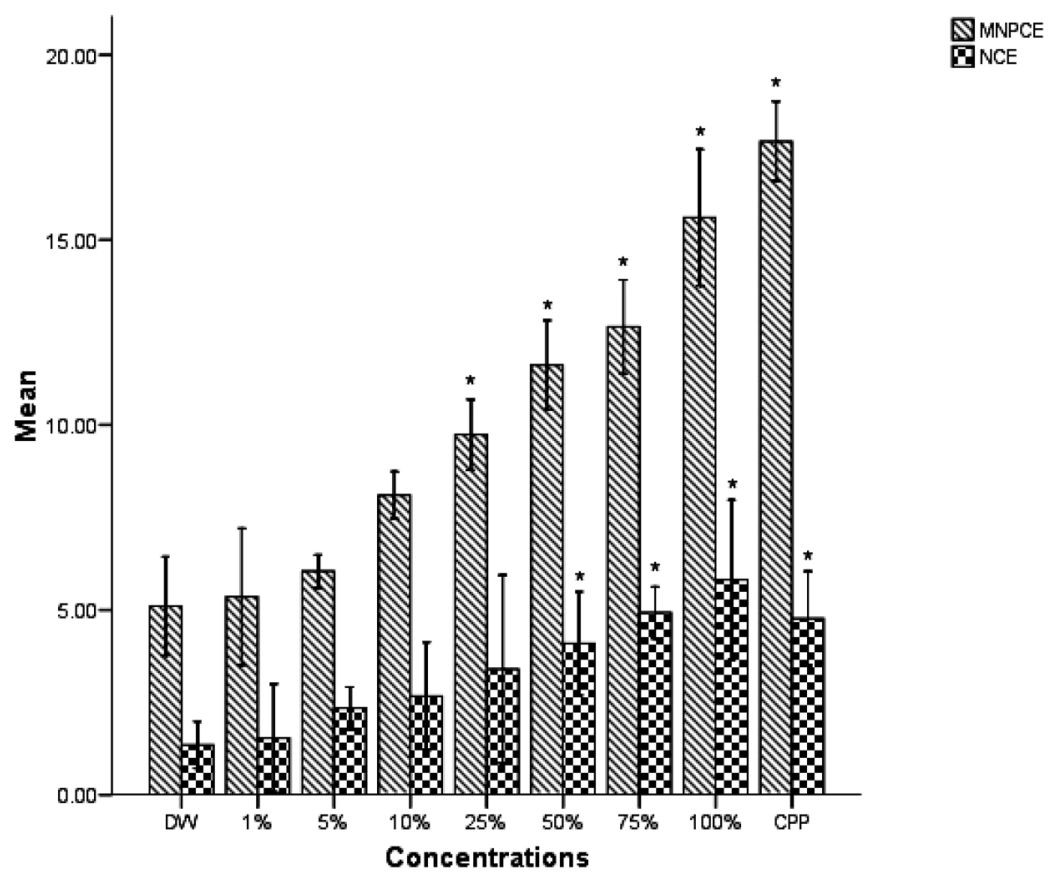

Fig. 1. The mean of MNPCE and NCE induced in mice exposed to different concentrations of tobacco industry wastewater. DW, distilled water; CPP, cyclophosphamide. * Significant at $p<0.05$.

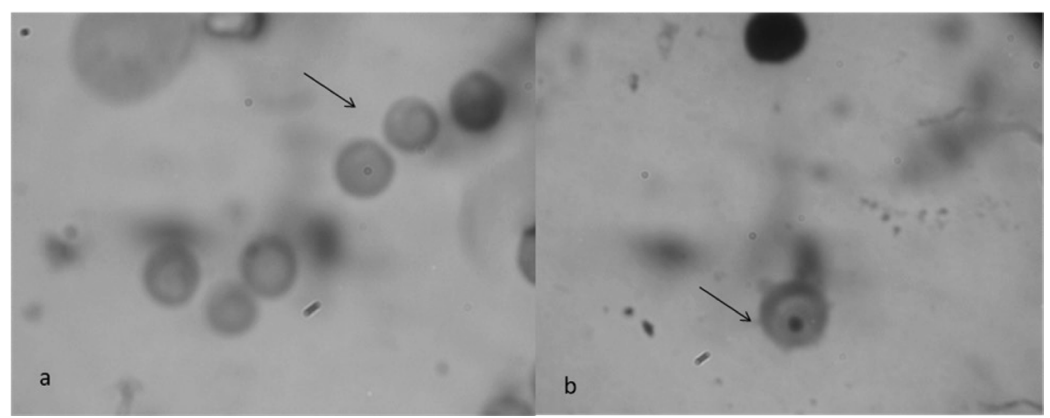

Fig. 2. Normal PCE (a) and MNPCE (b) observed in the bone marrow of mice exposed to the tobacco industry wastewater (May Grunwald and Giemsa stain, magnification $\times 100$ ).

significant $(p<0.05)$ and concentration-dependent at 25, 50, 75 and 100\% concentrations. Generally, sperm with an amorphous head were the most prominent (38.1\%), whereas banana-shaped sperm cells had the least occurrence (2.0\% occurrence) (Fig. 4). The percentage increase in the mean of induced abnormalities compared to the negative control is shown in Fig. 5.

\section{Sperm count}

The negative control showed $32.02 \times 10^{6} \mathrm{~mL}$ while the positive control showed $17.12 \times 10^{6} \mathrm{~mL}$ mean sperm count, which is a $46.53 \%$ reduction (Table 3 ). The mean sperm count decreased significantly in a concentration-dependent manner at all tested concentrations but was statistically significant $(p<0.05)$ at 50,75 and $100 \%$ concentrations, which accounts for $31.26,36.95$ and $41.10 \%$ reduction, respectively, compared to the negative control (Fig. 5). The decrease in mean sperm count was significant with respect to inter-concentration variations but insignificant with respect to inter-animal variations. 


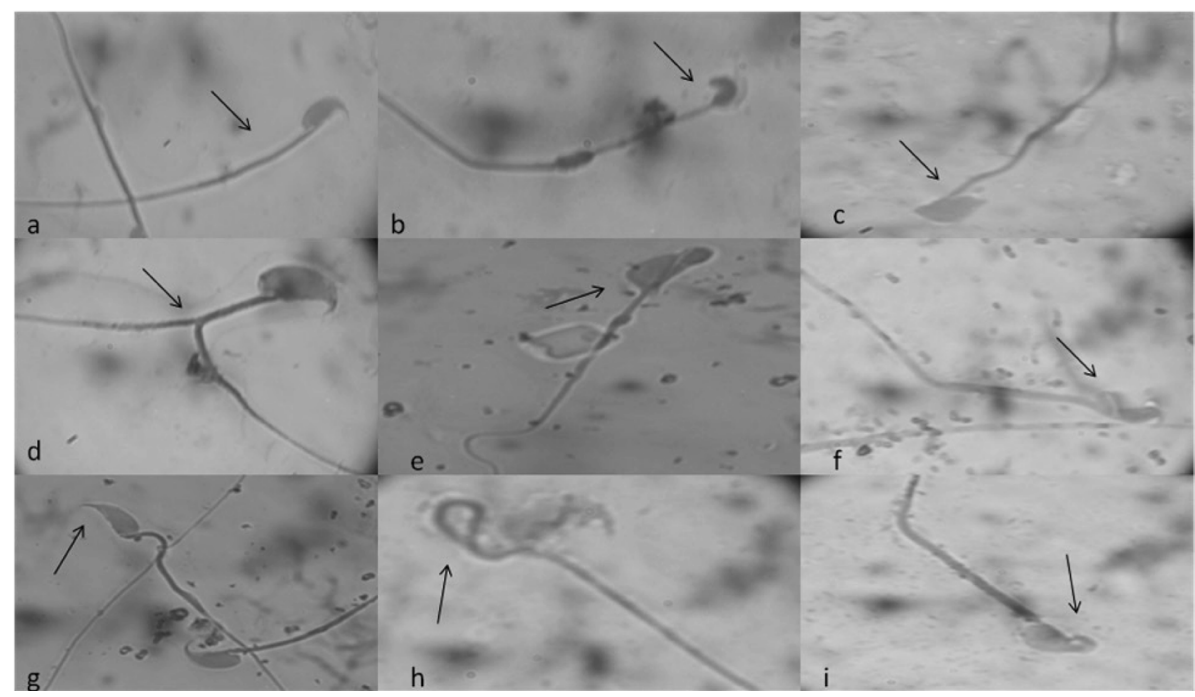

Fig. 3. Abnormal sperm cells induced in mice exposed to different concentrations of the tobacco industry wastewater (a) normal sperm cell, (b) pin head, (c) wrong tail attachment and amorphous head, (d) double-tailed sperm, (e) amorphous head, (f) banana head, (g) hook at wrong angle, (h) folded sperm, (i) knobbed hook. Magnification $\times 800$.

Table 2. Summary of morphologically abnormal sperm-heads induced in mice after five-week exposure to different concentrations of tobacco industry wastewater.

\begin{tabular}{lcccc}
\hline \hline Concentrations (\%) & $\begin{array}{c}\text { Number of } \\
\text { animals used }\end{array}$ & $\begin{array}{c}\text { Number of } \\
\text { sperms counted }\end{array}$ & $\begin{array}{c}\text { Number of } \\
\text { abnormal sperms }\end{array}$ & $\begin{array}{c}\text { \% Frequency of } \\
\text { abnormality }\end{array}$ \\
\hline Distilled water & 5 & 5000 & 96 & 1.92 \\
1 & 5 & 5000 & 98 & 1.96 \\
5 & 5 & 5000 & 127 & 2.54 \\
10 & 5 & 5000 & 201 & 4.02 \\
25 & 5 & 5000 & 275 & $5.50^{*}$ \\
50 & 5 & 5000 & 502 & $10.04^{*}$ \\
75 & 5 & 5000 & 582 & $11.64^{*}$ \\
100 & 5 & 5000 & 657 & $13.14^{*}$ \\
Cyclophosphamide & 5 & 5000 & 875 & $17.50^{*}$ \\
$(20$ mg/kg body weight) & & & & \\
\hline
\end{tabular}

* Significant at $p<0.05$.

\section{Discussion}

Large quantities of tobacco wastewater are generated during processing and cigarette-making, and these wastes may be toxic due to the presence of alkaloids, nicotines and tannins (Sax and Lewis 1989, Meher et al. 1995). Therefore, this study aimed at assessing the genotoxicity of tobacco wastewater using micronucleus and sperm morphology assays in mice. The data obtained in this study showed that tobacco wastewater is genotoxic in mice. There was induction of micronuclei in the bone marrow and sperms with different morphological abnormalities in the exposed mice.

The induction of micronuclei by the wastewater is an indication that the sample contained constituents that are aneugenic and clastogenic. Micronucleus assay explores the principle of erythropoiesis to detect the clastogenicity, aneugenicity and spindle poisoning potential of a 


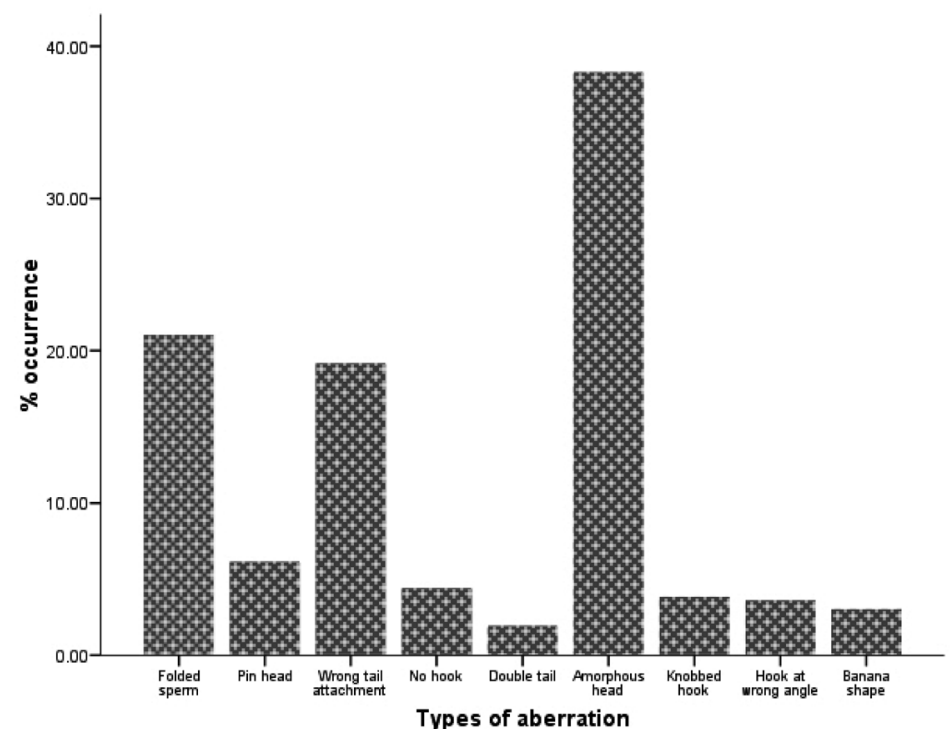

Fig. 4. The percentage occurrence of the different types of abnormal sperm cells induced in mice exposed to different concentrations of tobacco industry wastewater.

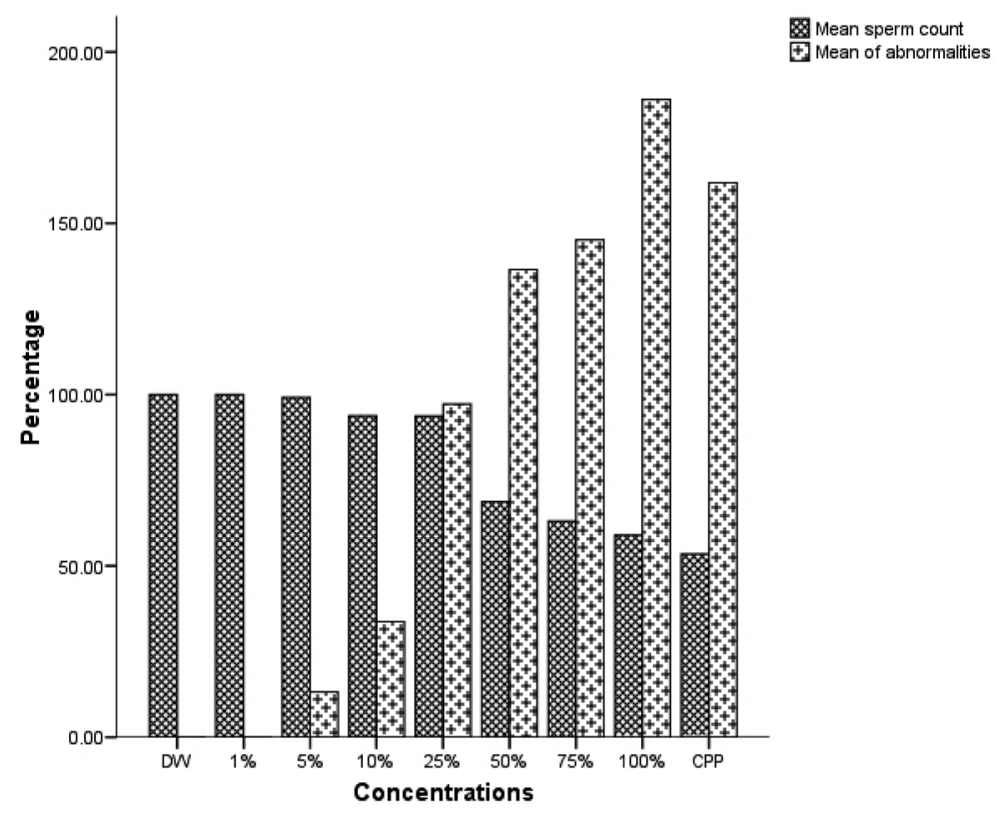

Fig. 5. The percentage reduction of mean sperm count and percentage increase in mean abnormalities compared to negative control in mice exposed to different concentrations of tobacco industry wastewater.

substance (Krishna and Hayashi 2000). The process of erythropoiesis in the hematopoietic organs (bone marrow and spleen) involves the proliferation and maturation of stem cells. The administration of tobacco wastewater during cell proliferation might have caused chromosome damage, and the wastewater might have acted on the macromolecules related to the function of chromatid disjunction (e.g., tubulin) causing spindle dysfunction, depending on the mechanism of 
Table 3. The mean sperm count of mice exposed to different concentrations of tobacco industry wastewater.

\begin{tabular}{lcc}
\hline \hline Concentrations (\%) & Number of animals used & Mean (mL) sperm count \\
\hline Distilled water & 5 & $32.02 \times 10^{6}$ \\
1 & 5 & $32.04 \times 10^{6}$ \\
5 & 5 & $31.76 \times 10^{6}$ \\
10 & 5 & $30.04 \times 10^{6}$ \\
25 & 5 & $30.01 \times 10^{6}$ \\
50 & 5 & $22.01 \times 10^{6 *}$ \\
75 & 5 & $20.19 \times 10^{6 *}$ \\
100 & 5 & $18.86 \times 10^{6 *}$ \\
Cyclophosphamide & 5 & $17.12 \times 10^{6 *}$ \\
$(20 \mathrm{mg} / \mathrm{kg}$ body weight) & & \\
\hline
\end{tabular}

* Significant at $p<0.05$.

action. These anomalies (a fragment or a whole chromosome) may lag behind in the cell during cell division and may not become integrated into the daughter nuclei, but rather may eventually form micronuclei, which can be seen in the cytoplasm (Krishna and Hayashi 2000). The micronucleus bioassay has been recommended for both in vitro and in vivo routine toxicological assessment of chemicals and wastes (ICPEMC 1983, Heddle et al. 1983, Cimino 2006). The in vivo procedure used in this study is of more relevance to assessing genotoxic potential to humans, putting into consideration metabolism, pharmacokinetics and other biological activities (Schmid 1975).

While the increase in the frequency of MNPCEs in the tobacco wastewater-treated mice is indicative of induced chromosome damage, the PCE-to-NCE ratio between the wastewater-treated mice and the negative control mice provides a cytotoxic index. The increase in the frequency of $\mathrm{NCE}$ in exposed mice is an indication that the tobacco wastewater constituents increase the rate of ageing of PCE to NCE, thereby decreasing their normal life span and hence increasing their risk of genotoxicity.

The result of the sperm morphology assay showed a significant increase in the induction of aberrant sperm cells. The induction of the sperm head abnormality in this study can be either due to impaired spermatogenesis or damage in the genetic material of spermatogonia and spermatocytes. Tasdemir et al. (1997) reported that abnormality in the sperm head morphology reflects abnormality in spermatogenesis. Also, Wyrobek et al. (1983) reported that agents inducing abnormalities in the sperm head interfere either with the integrity of the DNA itself or with the expression of the genetic material. Sperm analysis is one of the most reliable end points to investigate the effects of different chemicals on male reproductive health. Among the various etiologies attributed to the cause of male infertility, sperm DNA damage is highly significant. The integrity of sperm DNA is of vital importance for successful fertilization, embryogenesis and embryo development. Damage to sperm DNA may result in abnormalities of sperm morphology by affecting the differentiation of spermatogenetic stem cells. The sperm head morphological evaluation is used for the detection of abnormality in the sperm head, which indirectly indicates the mutagenic potential of a chemical (Koch et al. 1989). Evaluation of sperm head morphology is an old but rapid and inexpensive technique for the screening of different agents, which might be mutagenic, teratogenic and carcinogenic in nature (Wyrobek and Bruce 1975). The results in this study therefore showed that tobacco wastewater contained germ cell mutagens. A germ cell mutagen is an agent that induces (heritable) mutations in germ cells. Detection and characterization of DNA adducts formed by the germ cell mutagens provide evidence to the etiology of the developmental abnormalities and cancer induction in the offsprings (Phillips and Arlt 2009). Our data showed that the wastewater constituents were capable of interacting with the genetic processes involved in spermatogenesis in mice. This was corroborated by a significant decrease in the mean 
sperm count of exposed mice when compared with the negative control. This indicates that tobacco wastewater was not only capable of altering spermatogenesis, but also of reducing or destroying the viability of sperm cells. This therefore suggests that the sample contained constituents which are not only able to produce damaged sperm cells which might be unable to fertilize ovum or produce mutated zygote, but are also capable of reducing viable sperm cells, which is a major factor leading to infertility.

We could not find in the literature the genotoxicity of tobacco wastewater using micronucleus and sperm morphology assays. However, the results of this study are in accordance with the reports of Sponza (2002), where tobacco wastewater was shown to be toxic in conventional short-term bioassays using floc forming, fecal and total coliforms and enrichment toxicity test. One laboratorybased study has shown that cigarette butt leachates can kill water fleas (Daphnia species) in relatively low concentrations (Micevska et al. 2006). Slaughter et al. (2011) demonstrated that the median lethal dose is approximately one cigarette butt per litre of water for both freshwater and saltwater test fish species.

The observed genotoxicity of tobacco wastewater in this study is believed to be caused by the constituents, some of which were analysed in this study. This opinion is supported by the report of Micevka et al. (2006), which suggested that the toxicity of cigarette butt leachates is in part due to heavy and trace metals. The result of the physico-chemical analysis in this study showed higher levels of BOD, alkalinity, nitrate, phosphate, ammonia, cadmium, copper, iron, zinc, nickel and cobalt than tap water and the allowable limit for drinkable water quality (NESREA 2009, USEPA 2009). The occurrence of metals in tobacco wastewater can largely be attributed to the growth and cultivation of tobacco (Nicotiana tabacum), as tobacco is known to readily accumulate metals from the underlying soil (Tso 1990). The metal composition of the soil primarily reflects the mineral composition of the bedrock from which it was derived. The application of pesticides, insecticides, herbicides and fertilizers also introduce metals to the tobacco leaf (Frank et al. 1987). Further introduction occurs during cigarette manufacture, particularly via the addition of casing materials to the cured leaves (Baker et al. 2004) and the use of brightening agents on the wrapping paper (Owens 1978, Iskander 1985). The high heavy metal concentration in tobacco wastewater is in accordance with previous reports. Cigarette butts have been shown to leach out numerous chemicals such as heavy metals, nicotine and ethylphenol in water and may be a continual point source for contamination of aquatic environments after discarding (Moerman and Potts 2011). It has been suggested that DNA damage induced by leachates might be due to the presence and interactions of heavy metals with DNA (Alabi and Bakare 2011). The genotoxic activities of heavy metals were reported to be the result of formation of DNA-DNA and DNA-protein cross-links (DeFlora et al. 1990). These metals have the potential to induce mutation and cancer in living cells. A mixture of these may result in synergistic chemical combinations that are more harmful than the individual constituent itself. There is also the possibility of other constituents in the sample (though not analyzed) that might be responsible for the observed mutagenicity and genotoxicity in this study. A report (U.S. Department of Health and Human Services 2004) has shown that tobacco contains at least 4000 chemicals, with about 50 of those being carcinogenic.

In conclusion, tobacco wastewater is found to be genotoxic in mice using the bone marrow micronucleus and sperm morphology assays in this study. The wastewater contained heavy metals in higher concentration than the control and standards set by regulatory authorities. The observed genotoxicity and mutagenicity was believed to be caused by the constituents, some of which were analyzed. This result is important considering the ineffective regulations on the treatment of wastewater before disposal and the subsequent indiscriminate disposal of such wastes into the environment in developing nations. 


\section{References}

Alabi, O. A. and Bakare, A. A. 2011. Genotoxicity and mutagenicity of electronic waste leachates using animal bioassays. Toxicol. Environ. Chem. 93: 1073-1088.

Alabi, O. A., Omosebi, O., and Chizea, I. 2013. Determination of the mutagenic and genotoxic potential of simulated leachate from an automobile workshop soil on eukaryotic system. Toxicol. Ind. Health. DOI: $10.1177 / 0748233713483206$.

APHA 1998. Standard Methods for Examination of Water and Wastewater, 20th Edition. APHA, Washington, DC, USA.

Baker, R. R., Pereira da Silva, J. R., and Smith, G. 2004. The effect of tobacco ingredients on smoke chemistry, part I: flavourings and additives. Food Chem. Toxicol. 42S: S3-S7.

Bartke, A. J., Weir, A., Mathison, P., Roberson, C., and Dalterio, S. 1974. Testicular function in mouse strains with different age of sexual maturation. J. Hered. 65: 204-208.

Chidambara R. C. B. and Han, L. Q. 2004. Advanced oxidation processes for wastewater treatment: Optimization of UV/ $\mathrm{H}_{2} \mathrm{O}_{2}$ process through a statistical technique. Chem. Eng. Sci. 60: 5305-5311.

Cimino, M. C. 2006. Comparative overview of current international strategies and guidelines for genetic toxicology testing for regulatory purposes. Environ. Mol. Mutagen. 47: 362-390.

CIOMS 1985. International guiding principles for biomedical research involving animals (http://www.cioms.ch/publications/ guidelines/1985_texts_of_guidelines.htm).

DeFlora, S., Begnasco, M., Serra, D., and Zanacchi, P. 1990. Genotoxicity of chromium compounds. Mutat. Res. 238: 99178.

Frank, R., Braun, H. E., and Suda, P. 1987. Pesticide residues and metal contents in flue-cured tobacco and tobacco soils of southern Ontario, Canada 1980-1985. Tobacco Science 21: 40-45.

Gönen, Ç. 2005. Treatment of tobacco industry wastewaters by advanced oxidation processes. A thesis submitted to the Graduate School of Natural and Applied Sciences of Dokuz Eylül University. Dokuz Eylül University, İzmir. pp. $1-78$.

Heddle, J. A., Hite, M., Kirkhart, B., Marvurnin, K., MacGregor, J. T., Newell, G. W., and Salamone, M. F. 1983. The induction of micronucleus as a measure of genotoxicity: A report of the U.S. Environmental Protection Agency Gene-Tox program. Mutat. Res. 123: 61-118.

ICPEMC - International Commision for Protection against Environmental Mutagens and Carcinogens, 1983. Regulation approaches to the control of environmental mutagens and carcinogens. Mutat. Res. 114: 179-216.

Iskander, F. Y. 1985. Determination of trace elements in cigarette filter before and after smoking. J. Radioanal. Nucl. Chem. 91: 191-196.

Koch, S., Kramer, A., Stein, J., Adrian, V., and Weuffen, W. 1989. Mutagenicity testing in the sperm head test/mouse and mutagenic potency of 2 disinfectants on the basis of peracetic acid and phenols, respectively. Zentralbl. Hyg. Umweltmed. 188: 391-403.

Krishna, G. and Hayashi, M. 2000. In vivo rodent micronucleus assay: Protocol, conduct and data interpretation. Mutat. Res. 455: 155-166.

Meher, K. K., Panchwagh, A. M., Rangrass, S., and Gollakota, K. G. 1995. Biomethanation of tobacco waste. Environ. Pollut. 90: 199-202.

Micevska, T., Warne, M. St. J., and Pablo, F. 2006. Variation in, and causes of, toxicity of cigarette butts to a cladoceran and microtox. Arch. Environ. Contam. Toxicol. 50: 205-212.

Moerman, J. W. and Potts, G. E. 2011. Analysis of metals leached from smoked cigarette litter. Tob. Control 20 (Suppl. 1): i28-i32.

National Environmental Standards and Regulation Enforcement Agency (NESREA). 2009. (Federal Republic of Nigeria Official Gazette), National Environmental (sanitation and waste control). Published by Federal Government of Nigeria printer, Abuja FGP 112/102009/L000 (OL54). No. 60 (96), pp. 1057-1102. Accessed on 05/02/2013.

Novotny, T. E., Lum, K., and Smith, E. 2009. Cigarettes butts and the case for an environmental policy on hazardous cigarette waste. Int. J. Environ. Res. Public Health 6: 1691-1705.

Novotny, T. E. and Zhao, F. 1999. Consumption and production waste: Another externality of tobacco use. Tob. Control 8: 75-80.

Owens, W. F. 1978. Effect of cigarette paper on smoke yield and composition. Recent Ad. Tobacco Sci. 4: 3-24.

Phillips, D. H. and Arlt, V. M. 2009. Genotoxicity: damage to DNA and its consequences. EXS 99: 87-110.

Production of Tobacco 2005. www.yapraktutun.gov.tr. Accessed on 28/06/2012.

Rastogi, P. B. and Levin, R. E. 1987. Induction of sperm abnormalities in mice by quercetin. Environ. Mutagen. 9: 255260.

Sax, N. I. and Lewis, R. J., Jr. 1989. Dangerous Properties of Industrial Materials. Van Nostrand Reinhold, New York. p. 248.

Schmid, W. 1975. The micronucleus test. Mutat. Res. 31: 9-15. 
Schmid, W. 1976. The micronucleus test for cytogenetic analysis. In: Hollander, A. (ed.). Chemical Mutagens, Principles and Methods for Their Detection, Vol. 4. Plenum Press, New York.

Slaughter, E., Gersberg, R. M., Watanabe, K., Rudolph, J., Stransky, C., and Novotny, T. E. 2011. Toxicity of cigarette butts, and their chemical components, to marine and freshwater fish. Tob. Control 20 (Suppl. 1): i25-i29.

Sponza, D. T. 2002. Toxicity studies in a tobacco industry biological treatment plant. Water Air Soil Pollut. 134: $137-164$.

Tasdemir, I., Tasdemir, M., Tavukcuoglu, S., Kahraman, S., and Biberoglu, K. 1997. Effect of abnormal sperm head morphology on the outcome of intracytoplasmic sperm injection in humans. Hum. Reprod. 12: 1214-1217.

Tso, T. C. 1990. Production, Physiology, and Biochemistry of Tobacco Plant. Ideals, Inc., Beltsville, MD. Chapter 21, pp. $427-486$.

U.S. Department of Health and Human Services 2004. The Health Consequences of Smoking: A Report of the Surgeon General. US Department of Health and Human Services, Centers for Disease Control and Prevention, National Center for Chronic Disease Prevention and Health Promotion, Office on Smoking and Health, Atlanta.

United State Environmental Protection Agency (USEPA) 1996. Acid digestion of sediments, sludges and soil method3050B. USEPA, Washington, DC.

United State Environmental Protection Agency (USEPA) 2009. Drinking water contaminants. Washington, DC: USEPA. $\mathrm{http} / /$ water.epa.gov/drink/contaminants/index.cfm\#List.

World Tobacco Consumption 2005. www.rshm.saglik.gov.tr. Accessed on 28/06/2012.

Wyrobek, A. J. and Bruce, W. R. 1975. Chemical induction of sperm abnormalities in mice. Proc. Natl. Acad. Sci. U.S.A. 72: 4425-4429.

Wyrobek, A. J., Gordon, L. A., Burkhart, J. G., Francis, M. W., Kapp Jr., R. W., Letz, G., Malling, H. G., Topham, J. C., and Whorton, M. D. 1983. An evaluation of the mouse sperm morphology test and other sperm tests in nonhuman mammals. A report of the United States Environmental Protection Agency Gene-Tox Programme. Mutat. Res. 115: 1-72. 